\title{
RELIABLE AND PRACTICAL GUIDELINES FOR PLANNING AN EFFECTIVE ENGLISH LESSON
}

\author{
Mayra Solís Hernández
}

\begin{abstract}
RESUMEN
El objetivo de este artículo es ayudar a los estudiantes de la enseñanza del inglés a preparar planes de lección más efectivos, y a la vez proveerlos de una guía confiable y práctica que les facilite ese proceso de preparación para sus clases. Además, este artículo les brinda un formato sencillo, pero útil, para confeccionar un plan de lección. Tanto este formato como las ideas y la guía que aquí se presentan son producto de siete años de experiencia de la autora impartiendo los dos últimos cursos del programa de Posgrado en la Enseñanza del Inglés de la Universidad de Costa Rica: Diseño de Curso y Práctica Profesional.

Palabras clave: preparación de lecciones, enseñanza del inglés, capacitación de docentes, práctica docente, lecciones efectivas.
\end{abstract}

\begin{abstract}
The aim of this article is to help student teachers develop their planning skills and to provide insight into lesson preparation. This article presents reliable and practical guidelines to prepare effective English lessons. These basic principles have arisen from my seven-year experience teaching the practicum for the Master's program in Teaching English as a Foreign Language at the University of Costa Rica. A lesson plan format is also suggested as a useful tool for both trainees and teacher trainers in the field of English teaching. This template has proven to be very useful during the Practicum and has been highly recommended by the trainees in this program.

Key words: lesson planning, English teaching, teacher training, practicum, effective lessons.
\end{abstract}

\section{Introduction}

In Costa Rica, and probably in many other cultures, organizing a social event such as a party requires a great deal of thinking and preparation. Since a party is always expected to be an enjoyable experience, the organizer should pay attention to all the details that will contribute

\footnotetext{
Mayra Solís Hernández. Profesora de inglés. Escuela de Lenguas Modernas de la Universidad de Costa Rica. Correo electrónico: mayras@cariari.ucr.ac.cr
}

Recepción: 17- 9- 2008

Aceptación: 23- 10- 2008 
to the success of the activity such as food, music, and gifts. Likewise, when English teachers plan their lessons, they also have to take into account several variables to make sure that their lessons are going to be effective. Some of these variables include a purpose, a topic, a person in charge of the event, participants, content, an organized way to conduct the events following logical steps, arrangements to be done prior to the events, feelings, a place, a time period, and problem anticipation. The following table summarizes the elements to be considered when organizing a surprise party and preparing an English lesson.

Table 1. Elements that both events, organizing a surprise party and preparing an English lesson, have in common

\begin{tabular}{|c|c|c|}
\hline Elements & A surprise party & An English lesson \\
\hline Organizer & the host / hostess & the teacher \\
\hline Participants & the guests & the students \\
\hline Purpose & to celebrate a special occasion & $\begin{array}{l}\text { to teach / learn specific } \\
\text { content }\end{array}$ \\
\hline Topic & a farewell, promotion, birthday & $\begin{array}{l}\text { a teaching point (grammar, } \\
\text { skills, vocabulary, etc.) }\end{array}$ \\
\hline Content & enough food and drinks & $\begin{array}{l}\text { appropriate language, } \\
\text { skills, strategies }\end{array}$ \\
\hline Method & entertainment activities & learning activities \\
\hline Procedures & $\begin{array}{l}\text { protocol / etiquette: social rules to be } \\
\text { followed to make the event a success }\end{array}$ & $\begin{array}{l}\text { necessary steps to be taken } \\
\text { to make the activities fit } \\
\text { into the lesson as a whole }\end{array}$ \\
\hline $\begin{array}{l}\text { Prior-to-the } \\
\text { event arrangements }\end{array}$ & $\begin{array}{l}\text { music / hiring musicians } \\
\text { or entertainers }\end{array}$ & $\begin{array}{l}\text { getting equipment ready } \\
\text { and preparing materials }\end{array}$ \\
\hline Excitement & a surprise happening & $\begin{array}{l}\text { something new in each } \\
\text { lesson }\end{array}$ \\
\hline Setting & comfortable and large enough place & $\begin{array}{l}\text { relaxed atmosphere and } \\
\text { comfortable classroom }\end{array}$ \\
\hline Length & a specific period of time & $\begin{array}{l}\text { time allotted for the } \\
\text { lesson }\end{array}$ \\
\hline Problem anticipation & $\begin{array}{l}\text { attention given to possible problems } \\
\text { (for example, seating arrangement, } \\
\text { weather conditions) }\end{array}$ & $\begin{array}{l}\text { attention given to possible } \\
\text { problems (for example, } \\
\text { difficult grammar } \\
\text { structures, troublesome } \\
\text { phonological issues / } \\
\text { new vocabulary) }\end{array}$ \\
\hline
\end{tabular}

As can been seen in Table 1, to prepare an effective English lesson and to organize a surprise party, both the teacher and the host or hostess have to pay careful attention to the same variables if they want the activity to be a success. A very important aspect that should not be neglected in either event is the "surprise" element. The fact that the party is a surprise causes excitement among the guests, and these intense feelings are precisely the same emotions that teachers want their students to experience in any class. In other words, teachers should strive to keep the students motivated in their classes as if they were enjoying a 
surprise party because a surprise element in each lesson not only increases student motivation but also enhances learning.

Before defining what a good lesson plan is and what it should include, it is important to describe what a good lesson should be. Woodward (2001: 2) mentions eleven criteria for a good language lesson; I would like to highlight four of them at this point:

A good lesson is one where there is plenty of language learning going on and where the students and I [the teacher]:

- feel comfortable physically, socially and psychologically

- accept that language is a mixture of things (part instinct, motor skill, system, cultural artifact, music, part vehicle for content and part content itself), that it changes all the time and thus that we need to teach and learn it in a variety of ways

- do things in class that would be worth doing and learn things that are worth learning for their own sake outside the language classroom

- become more capable of taking the initiative, making decisions and judging what is good and useful.

Having stated the salient characteristics of a good lesson, we now turn to define lesson plans. Bailey (1996: 18) believes that a lesson plan is "like a road map which describes where the teacher hopes to go in the lesson, presumably taking the students along." This simple but very precise definition implies that teachers should try to draw this road map as clearly and carefully as they can so that the students do not get lost on their "academic trip." From our own experience as students in any stage of our lives, we certainly know that lessons may vary in length, topic, methodology, materials, and place. However, a not very obvious fact, which any experienced teacher will definitely agree with, is that all lessons require careful planning if their goal is to help students acquire language effectively. Lesson planning is a skill, and as such it has to be learned the same way we learn any other skills, for example, how to swim, how to write, or how to play a musical instrument. All teachers, novice or experienced, demonstrate their planning skills and thinking ability in their lesson plans. Experienced teachers sometimes reduce their lesson plans to an outline, but most novice teachers need very detailed lesson plans and notes to guide their performance and to feel more confident.

There is no best way to plan lessons, nor does a good lesson plan guarantee that students will learn what is intended; however, a good lesson plan undoubtedly contributes to effective learning. Lesson planning helps all teachers, especially novice ones, to organize content, materials, learning objectives, strategies, instructional procedures, assessment, and time allotted for each activity. Besides, by carefully planning a lesson, the teacher can anticipate grammar problems that students might encounter in their learning process, pronunciation mistakes that will need correction, and the useful language that students will require to communicate when working in pairs or groups.

This article intends to help student teachers develop their planning skills and to provide insight into lesson preparation. For seven years, the author has taught the last two required courses for the Master's program in Teaching English as a Foreign Language at the University of Costa Rica: Course Design and the Practicum. Course Design provides the students with four hours of instruction on designing an ESP course. The Practicum gives the trainees four hours of instruction and four hours of classroom teaching. In teams of 3, occasionally 4, the student teachers are asked to design and to teach a 56-hour ESP (English for Specific Purposes) course for mostly university personnel, and for each teaching session, they are required to submit a detailed lesson plan. After each lesson, there is a debriefing period with the observer and the other members of the team. While she was working as an observer professor, the author collected a great deal of feedback on lesson planning from student teachers and from other colleagues who participated in the observations. Thus, most 
of this valuable information is now presented in this article as reliable and practical guidelines for planning lessons. Besides, a lesson plan format is also suggested as a useful tool for both trainees and teacher trainers in the field of English teaching. This template has proven to be very useful during the Practicum and has been highly recommended by student teachers who were doing their their practicum.

\section{Theoretical background}

\subsection{Planning decisions}

Like any other educational activity, careful lesson planning involves making a large number of important decisions, which should be made after some deep reflection. One good way to start this process is for teachers to reflect on their beliefs about teaching and learning. The following set of questions provided by Richards and Lockhart (1995: 82) should be answered before beginning to write the lesson plan:

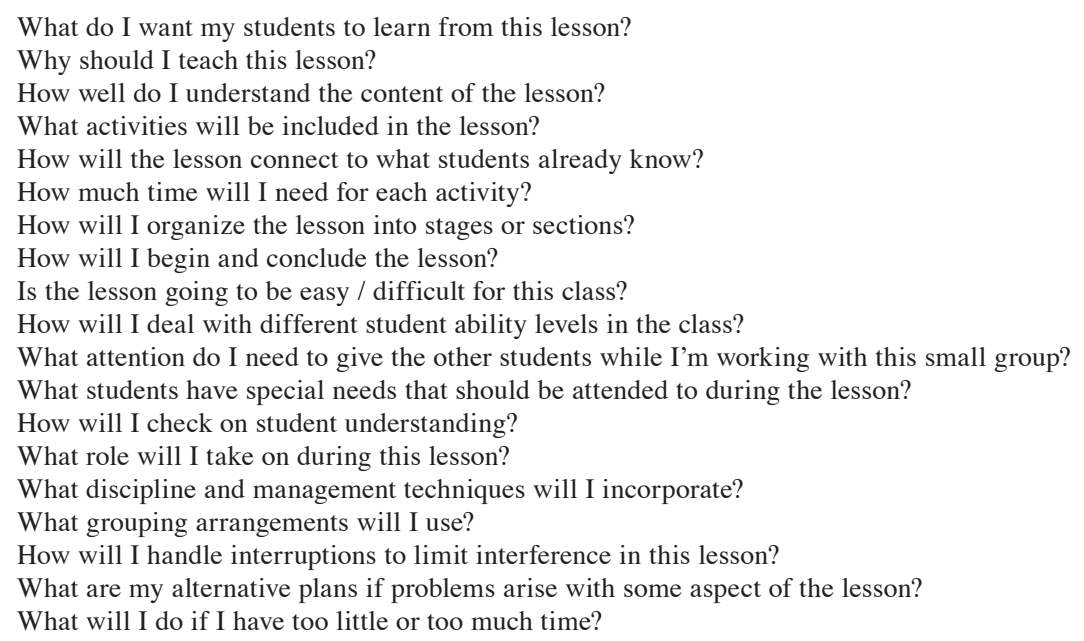

Even though these questions will guide the teacher in writing his lesson plan, instructors should not forget that the outcome of most lessons is unpredictable and that many unexpected situations can occur in the class. Therefore, the teacher should be open to make changes in the spur of the moment, always thinking about what is best for the students.

\subsection{Benefits of lesson planning}

The importance of writing effective lesson plans has been the focus of discussion of many authors, and most of them agree on the benefits that a good lesson plan brings to the class. Propst (1997: 47) claims that lesson planning helps the teacher consider the purpose of the lesson and the reason for each step, establish clear goals for the lesson that are understood by both the teacher and the learners, predict potential problems, make smooth transitions from one lesson to the next, keep a written record of the course, and examine the lessons critically in order to make improvements. Davies and Pearse (2000: 123) suggest making a few notes on the plan during or after the lesson and using them as the starting point for the following lesson plan. This helpful information may serve as the basis for even better plans when you teach the 
course again. Along with this line of thought, Doff (2000: 101) states that the main purpose of lesson plans is to help teachers decide exactly what they will do, how they will do it, and use the plan to evaluate what happened in the lesson that day. Another additional value mentioned by this author is that teachers may reuse those plans in following years.

Davies \& Pearse (2000: 148) also believe that "when you are working with a coursebook, planning is important because it can help you avoid potential problems in the material; exploit strengths, and convert the material into lively classroom activities; adapt the material to your learners' interests and needs, and to your own teaching style." They also claim that planning can also help you integrate book material with other appropriate material and ideas. (2000: 151)

Jensen (in Celce-Murcia 2001: 403) asserts that a lesson plan is a necessity for a substitute teacher on those occasions when a teacher has to miss a class. If the plan has been carefully prepared, the substitute teacher can just follow it and do what had been planned for the day. Jensen also adds that "as teachers expect their students to come to class prepared to learn, students come to class expecting their teachers to be prepared to teach, and a lesson plan is part of that preparation."

Finally, according to Woodward (2001: 181), lesson planning helps teachers reduce their feelings of uncertainty or panic, and instead, it inspires them with a sense of confidence and clarity. Besides, careful lesson planning inspires confidence in students as well, and as a consequence, they experience a feeling of purpose, progression and coherence.

\subsection{Essential elements of a lesson plan}

Many authors agree on the basic elements that a good lesson plan should include. Pang (cited in Richards 1998: 104) proposes a framework for lesson plans which includes objectives, the subject matter, approaches and methods, key questions, the introduction, the summary, methods for arousing interest, the timing for the different activities, appropriate audio-visual aids and their sources, a blackboard plan, worksheets, the homework or follow-up activities, objectives check, linkages and ways to explain, methods for evaluating learning outcomes, and a list of things to bring or to prepare. Jensen (in Celce-Murcia 2001: 404) adds some other elements to this long list: the date and the week of the course, grammatical structures, key vocabulary terms that will be introduced, reminders for the students, procedures and class management notes such as seating arrangements, and even a contingency plan which might prove very useful especially for novice teachers. Furthermore, according to Davies and Pearse (2000: 148) lesson plans based on textbooks can be quite simple, but they should also include objectives and the teaching points of the lesson, materials and activities, modifications you will make (different sequences, variations in exploitation), the supplementary material and equipment the teacher will need, classroom management and interactions for each activity, and the approximate time for each activity.

\subsection{Characteristics of good lesson plans}

Although there is a variety of lesson plans, most of them share certain characteristics. The three main features stated by Jensen (in Celce-Murcia 2001: 406-7) are coherence, variety, and flexibility. A lesson plan is coherent when there are smooth transitions from one activity to the next and when students can understand the rationale for each activity. For instance, after reading a text or listening to a passage, the teacher can ask the students to do a writing activity in which they have to use information from the previous activity. Besides, a good lesson plan should not follow the same pattern so that students do not get bored or fatigued; quite the 
opposite, lesson plans should exhibit some variety in terms of topics, types of activities, skills, pace, grouping techniques, and materials. A third characteristic that should be present in each lesson plan is flexibility; that is, a lesson plan is not cast in cement. As Woodward (2001: 1) clearly states, "Lesson plans are to help us shape the space, time, and learning we share with students. We can depart from them or stick to them as we, the students and the circumstances seem to need."

Moreover, lesson plans have to be created taking into account students' proficiency level, their ages, and the objectives to be achieved that day. The following quote by Davies and Pearse (2000: 122-3) reinforces this idea:

\begin{abstract}
Lesson plans need to vary according to the age and level of the learners, the objectives, the time of day, and even the time of year. Young learners need more changes of activity and more physical activity. They have much shorter attention spans than older learners, and can get very restless. Older learners at higher levels can sometimes work enthusiastically at the same task for quite long periods of time. Lessons at the end of a long morning, the end of a long day need to be lighter than other lessons.
\end{abstract}

\title{
2.5. Assessing lesson plans and lesson effectiveness
}

Once lesson plans are finished, and the instructors think they are ready to teach, they should devote some time to reflect on the quality of the documents. Richards and Lockhart (1995: 94) give us seven questions that can be used to evaluate the degree of success of lessons:

\footnotetext{
Are the students going to learn something in this lesson?

Are they going to enjoy the lesson? Is it likely to be fun, varied and satisfying?

Does the lesson as a whole have a sense of coherence and purpose?

Does the lesson connect up with what went before?

Is the lesson building on previous learning?

Does the lesson lead the way to useful activities in later lessons?

Is the lesson opening up new areas of knowledge and practice?
}

As a rule of thumb, if any of these questions is answered in the negative form, then the teacher should go back to the plan and modify it, providing the missing elements. Teachers should never go into a classroom with a lesson plan they are not really satisfied with because it may hinder the students' learning process, and they might end up feeling frustrated and deeply disappointed with teaching.

Teachers should not only reflect on a lesson before it is delivered to prevent some potential problems, but also they should assess its effectiveness once the lesson is over to decide what action is needed for improvement. Ur (1996: 219) suggests the following criteria for evaluating the lesson: The learners were active all the time; they were attentive and motivated all the time; they enjoyed the lesson; the class seemed to be learning the material well; the lesson went according to plan, and the language was used communicatively. Richards (1998: 110) used similar criteria to study teachers' beliefs about successful lessons: the lesson achieved aims; there was active student participation and language use; students used and practiced target language; the lesson was lively and enjoyable; students felt they were learning; the lesson covered all four skills; there was a variety of tasks; students felt positive and learned new and useful things.

\section{Guidelines for planning a successful English lesson}

A number of practical suggestions for lesson planning have arisen from my experience that may prove useful for novice teachers or trainees who find themselves attempting to prepare to teach exciting lessons in similar situations. 


\subsection{Select the main teaching point}

Before you start writing your plan, decide on the main teaching point which may be a task, a language pattern, a function, a skill, a strategy, and even a cultural aspect. If you have chosen to plan a task, list all the structures and vocabulary that the students need to carry it out successfully, and teach those items before the students are told to begin the task. Plan a pre-task phase as well as a post-task focusing on a specific language problem you might have encountered while students were performing the task. If, on the other hand, you decide to teach a language pattern, a function or any other aspect, you can use the presentation, practice and production sequence. In such a case, first, plan an activity to introduce the new aspect; then prepare some guided exercises, and finish with some communicative exercises. Following this framework, the students will feel at ease, and there will be some spontaneous production towards the end of the session.

\subsection{Anticipate difficulties}

Once you have chosen your teaching point, anticipate difficulties; that is, try to guess what errors are most likely to occur, and plan some strategies to correct them. If you think there may be a phonological difficulty, plan a pronunciation activity or a brief explanation, or if you foresee a grammatical problem, prepare some exercises to clarify possible doubts. Furthermore, think about possible questions related to your teaching point that your learners might ask you, and be prepared to answer them satisfactorily. Look for materials that will help you give the students a better answer and have them ready.

\subsection{Always teach something new}

Keep in mind that the surprise element mentioned at the beginning of this article should be a key factor in your lesson; therefore, plan to teach a new item or point in every lesson. Even if you have a review lesson for a special reason, include a couple of new expressions or a short text that presents new content or a cultural note. This way the students will feel that they have reviewed some previously introduced content but, at the same time, have learned something useful that day. Remember that new and useful content increases student motivation.

\subsection{Write clear goals and objectives}

Writing goals and objectives helps the teacher get a clear idea of what he will teach; therefore, a good lesson plan should begin with a goal and some objectives. Brown (1995: 21) defines goals as "general statements about what must be accomplished in order to attain and satisfy students' needs." Graves (2000: 75) states that "if we use the analogy of a journey, the destination is the goal; the journey is the course." Objectives, on the other hand, are "precise statements about what content or skills the students must master in order to attain a particular goal" (Brown 1995: 21). In other words, goals are what the students should be able to do when they finish the course, and objectives are what the students will be able do at the end of each lesson.

When you are formulating the objectives, avoid using verbs that are vague or difficult to observe or measure, for example, learn, practice, or enjoy. Instead, use phrases that can be easily verified such as produce appropriate polite forms of apologizing or initiate and sustain a conversation, face-to-face, with an English speaking visitor. Besides, each objective should 
include at least three important components: performance (what the student will be able to do at the end of the lesson), conditions (the circumstances that surround the performance) and criterion (the level of accuracy that will be considered sufficient to succeed) (Brown 1995: 87-90).

\subsection{Include the language you expect your students to learn}

As mentioned earlier, in a successful lesson, students practice and produce the target language; hence your plan should include the language that you want your students to learn in that lesson. Do not just make a list of isolated words; instead, include collocations, "groups of words that belong together, either because they commonly occur together like to take a chance or because the meaning of the group is not obvious from the parts, as with by the way or to take someone in (trick them)" (Nation 2001: 317). Collocations are important to generate natural language, to develop fluency, and to prevent students from making serious mistakes. In addition, write down the language that your students will need to interact before, during and after each activity. Again, it is better to teach this useful language in sense groups of words, for instance, Shall I go first?, What do we do now?, What is the meaning of this word?, I don't understand this phrase, or Please, speak more slowly.

\subsection{Plan purposeful classroom activities and present them in a logical sequence}

Plan classroom activities that are meaningful and lively; that is, they should address your students' interests and needs, and they should also bring some excitement and fun to the class. Besides, any activity that the students do must contribute to achieve a teaching objective; otherwise, you and your students will be wasting invaluable class time. Plan to start your lesson with a warm-up activity (no more than 10 minutes) to motivate the students. Make sure they are relaxed and attentive and that most of them have al least a short intervention. Warm-ups are varied in type and purpose, and they can be very specific depending on the type of students you are teaching, but since they are very short, they are usually very controlled activities, for example, guessing games, questions-answers, mimes, scrambled sentences, jokes, comic strips, cued dialogues, and even relaxation techniques.

For a lesson to be effective, it is essential that you establish a logical sequence of activities taking into account your students' variation of ability. Design activities that include some easy items and some difficult ones; remember to assign easy tasks or items to low-level students and harder ones to those who are more proficient; this rule also applies when you ask your learners questions to elicit information. The hardest tasks should come early in the lesson because students are usually more energetic at the beginning of the session, and they can do those tasks that demand more effort and concentration in a better way. Whenever possible, model or demonstrate the task so that all the students, even the slowest ones, understand the instructions. Moreover, try to balance the different types of activities included in the lesson, and make sure you integrate different skills; vary the pace to suit the students' levels of concentration and energy at different stages of the lesson.

Finally, keep in mind that the following pieces of advice are likely to help you plan your lessons: Have quieter activities before lively ones (after an exciting activity like a game or competition, it is very difficult to calm down a class); plan smooth transitions between two activities; always have a "reserve"activity in case you have some extra time (a game, for example); and note which activity you will sacrifice in case you do not have enough time for everything planned. Always end the lesson with an activity which the learners are very likely to succeed in. This will generate a feeling of satisfaction. 


\subsection{Plan strategies to personalize learning}

Personalization (Ur 1996: 281) means asking learners to perform tasks that have to do with themselves to increase motivation. Thus, in order to personalize learning, plan strategies to involve the students' lives and interests in the process; for example, ask your learners to express their opinions, to share their experiences, or to state their beliefs about a topic that they have just discussed. It is very likely that students will forget those textbook exercises that do not relate to their lives more easily than those that deal with their personal experience and background. Therefore, your lesson plan should include those strategies (e.g. questions) that you will ask your students to arouse their interest and enhance their learning.

\subsection{Gaining confidence}

One of the main purposes of having a detailed lesson plan when you go into a classroom is to help you feel confident and relaxed so that you can perform better, and an excellent way to achieve this is to do the activities yourself when you are planning your lesson. Do not just read the plan; actually do each task as if you were a student. Check every item to make sure there is no ambiguity in the wording, and write down all the possible responses. Also make sure the instructions are clear and easy to follow and that all the necessary materials are ready to use.

\subsection{Grouping techniques}

To multiply opportunities for class participation, to maximize learning time, and to avoid boredom in class, you should have various grouping arrangements: whole group, small groups, and pairs. Use different strategies to make the groups (e.g. assign numbers, letters, objects, cards, and colors). Plan to use as much pair and group work as possible since this will help your students feel relaxed, and it will increase their speaking opportunities. This also allows the teacher to walk around and monitor students' progress easily. Tip: If you want your students to work in pairs, but you have an odd number of students, to form a group of three, tell one student that he or she has a twin brother or sister and that they always work together.

\subsection{Assessment criteria}

An aspect that no teacher should forget when writing a lesson plan is assessment. Hopefully, there is some degree of student learning in each classroom activity; as a consequence, the teacher should prepare some assessment criteria for each task and list them in the lesson plan. These criteria may range from a mere observation to sophisticated grading scales, but even if you have decided to just observe the development of the activity to determine its degree of success, you should choose the aspects that will help you make a decision beforehand. In other words, you should decide in advance how you will collect evidence of the learners' performance and attitudes toward the class and include those criteria in your plan. Besides, if you plan to pay special attention to weak students, write down their names and the points you will be monitoring that day.

\subsection{Materials}

A key issue in planning a lesson is materials development. To create effective materials, always keep in mind that teaching materials should be aimed at achieving the objectives that will help the students reach the goals of the course. All your materials should be designed 
taking into account your learners' age, interests, and their learning styles: auditory, visual, kinesthetic, tactile (Díaz Maggioli 1995: 9-10; Williams and Burden 1997: 160-1). For example, if your students are more visual, they would prefer to see written language, pictures and charts. On the other hand, if they are more auditory, they would rather do listening exercises.

Moreover, you should choose those materials that you consider the most effective and list them next to each activity. Remember that the board is sometimes your best resource and that your teaching aids should be appealing, clear, and large enough for the whole group to see them clearly. All handouts should be error free. The language included in these handouts represents the model language that the students will use later in the activities; thus it should be natural and appropriate for each situation. Besides, each handout should include short instructions and the language that students will need to do each exercise. For example, if they are going to play a game, they may need expressions such as "It's my turn." or "You go next." Giving the students some useful language and practicing it before an activity reduces the use of their mother tongue in a foreign language class.

\subsection{Odds and ends}

This section presents advice that could not be classified into any of the previous categories, but the author considers it essential when you plan a lesson:

Include lots of review phases in your classes: at the beginning, in the middle, at the end, and after a few weeks. It is very easy to forget something if you do not review it. Recycle chunks of language, readings, listening passages, and activities in general.

Think about different ways to elicit words, structures, and content from your students before you start teaching an aspect. Perhaps a student already knows what you are trying to teach, and he can help you with the development of the lesson.

Write down the instructions for each activity and practice giving them. If they are long and complex, break them down and go one step at a time to reduce teacher talk. Remember that when you speak for a long time, you are probably losing your students in the process and denying them an English-speaking opportunity.

If you are planning to use some equipment, check it in advance. This advice might seem obvious, but technology sometimes plays tricks on teachers and embarrasses them in front of the class. To avoid this situation, watch videos and set your cassettes as you plan. If you are going to use a compact disk, write the track numbers in your plan; this will save valuable class time, and your learners will appreciate it.

\section{Sample Lesson Plan Format}

Thirteen student teachers, who were taking the course PF-0311 Professional Practicum to complete the Master's program in Teaching English as a Foreign Language at the University of Costa Rica, were required to use the following lesson plan template to prepare 24 lessons. When they finished the course, they were asked to express their opinions about the usefulness of the template using a rating scale from 0 (useless) to 5 (very useful) (Appendix 1). This format includes the sections that the author considers indispensable to effective planning: goal, objectives, procedures, language, strategies / skills, assessment criteria, a timeframe, materials, reminders, and homework. Each component was carefully explained to the student teachers in class before actually having them plan the lessons. Interestingly, at the beginning of the practicum, the lesson plans were extremely detailed, but at the end, they were more concise, clearer, and easier to follow. 


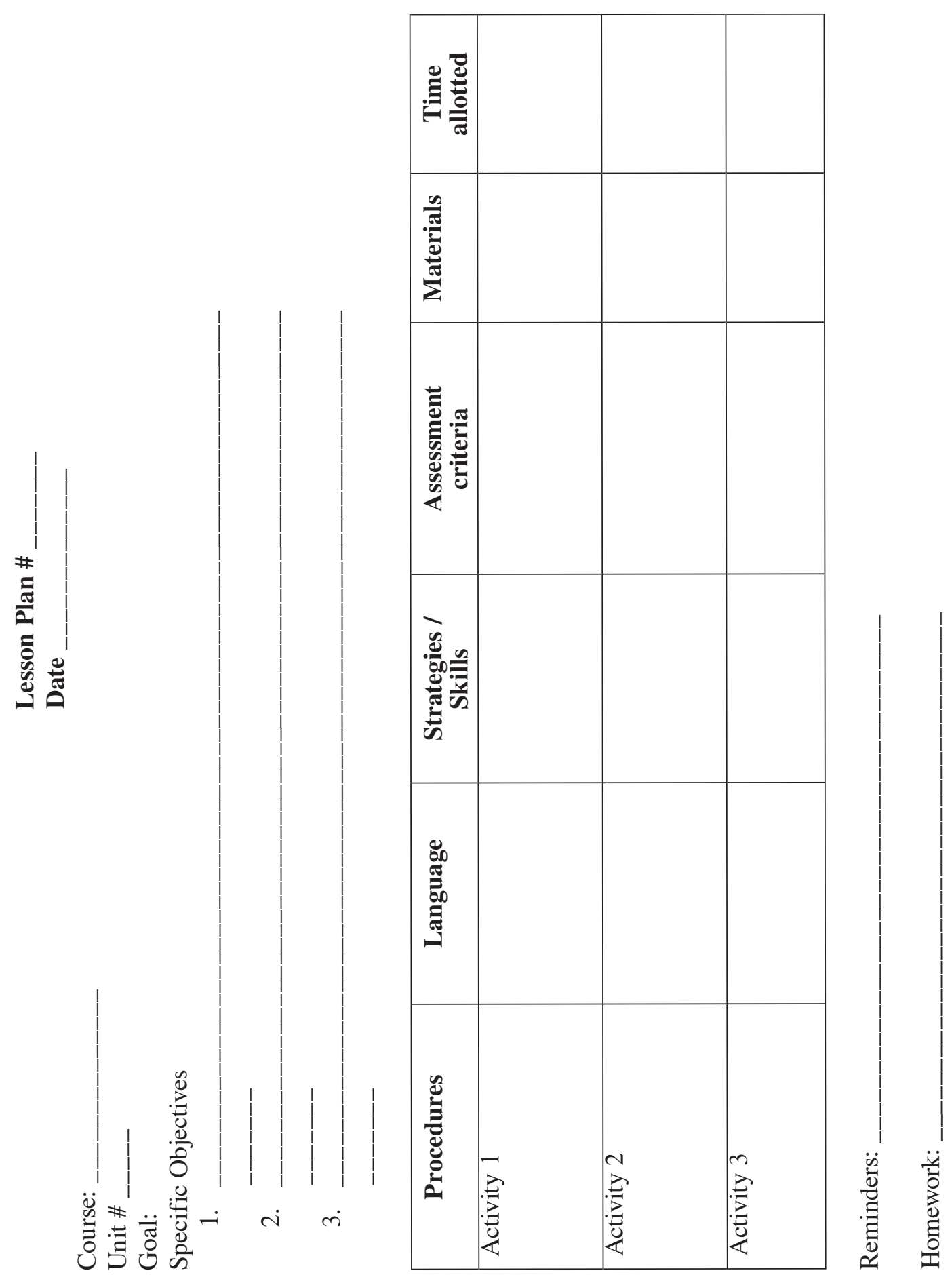


Table 2 summarizes the student teachers' beliefs about the usefulness of the template.

Table 2

Trainees' opinions about the usefulness of using the required template

\begin{tabular}{|c|c|c|}
\hline Student & Responses & Usefulness \\
\hline 1 & I found this template very useful and clear. & 5 \\
\hline 2 & $\begin{array}{l}\text { It was very useful and planning was less time-consuming } \\
\text { because I have the template ready on my computer. }\end{array}$ & 5 \\
\hline 3 & $\begin{array}{l}\text { This format includes many details, and it gives us a clear idea } \\
\text { of what we want to teach. }\end{array}$ & 5 \\
\hline 4 & Very useful! Planning was faster this way. & 5 \\
\hline 5 & $\begin{array}{l}\text { I consider it was very useful, especially the column for strategies } \\
\text { and assessment. Sometimes we forget about these two aspects } \\
\text { when planning. }\end{array}$ & 5 \\
\hline 6 & $\begin{array}{l}\text { It has been very simple to use. It has the most important elements } \\
\text { of a lesson, and it allows us to keep those aspects in order. }\end{array}$ & 5 \\
\hline 7 & It has been very useful. I got used to it very easily. & 5 \\
\hline 8 & It was simple to follow and easy to use in class. & 5 \\
\hline 9 & $\begin{array}{l}\text { It helped us organize our thoughts. It was also easy to } \\
\text { consult during class. }\end{array}$ & 5 \\
\hline 10 & It worked perfectly for our group. It made us enjoy planning. & 5 \\
\hline 11 & $\begin{array}{l}\text { The template has been very useful because we have a guide to } \\
\text { take us through the different parts of a lesson. }\end{array}$ & 5 \\
\hline 12 & It was useful because it helped me to keep my lesson in order. & 4 \\
\hline 13 & $\begin{array}{l}\text { This lesson plan format is very complete. I thought it was easy } \\
\text { to fill out. }\end{array}$ & 4 \\
\hline
\end{tabular}

Usefulness: 5: very useful <--------------- > 0: useless

As shown in Table 2, all the students chose 4 or 5 as their answers; this means that they considered the template useful or very useful in the practicum. Most of the students $(84.62 \%)$ were very satisfied with this format and rated its usefulness with the highest possible number (5), whereas $15.38 \%$ rated it a little lower (4). All the students included very positive comments about the format, and they described it using reassuring words. In general, they reported that the template had helped them plan in an orderly way, that it had reminded them of the aspects to include in the plan, and that the planning process had been enjoyable and less-time consuming. 


\section{Conclusions}

Planning adequately is a skill that novice and experienced teachers should develop and hone because well planned lessons increase teacher confidence. While planning, teachers anticipate problems and make provisions to solve them. They can even predict possible questions from the learners and make some notes to provide unequivocal answers. Moreover, by planning a lesson, a teacher can make sure the lesson is well balanced and appropriate for the class. This will ensure a smooth and logical lesson; thus teachers will feel relaxed and have a very rewarding teaching experience.

In order to plan effective lessons, the following acronym could be used to help teachers bear five basic principles in mind: OVUFA (Objectives, Variety, Usefulness, Flexibility, and Assessment). First, the plan should contain realistic objectives that can be fully achieved by the end of the lesson so that the learners leave the classroom with a feeling of accomplishment. Second, every lesson plan should include a variety of activities to keep students engaged and to satisfy their learning styles, needs and interests. Variety in the teaching process avoids boredom and fatigue, which are two main causes of student behavior problems. Third, usefulness should be a key word in planning, and here it refers to both useful materials and useful language. Teachers should create or adapt materials that are useful to help learners achieve the objectives of that lesson, and these aids should be designed on the basis of usefulness and cost effectiveness rather than on fun or entertainment. Furthermore, the plan should include useful language, defined here as the target expressions, chunks or patterns that will be taught that day and the language that the students will need for communicative purposes. Fourth, the lesson plan should be flexible. It is advisable to include some extra actvities in case the teacher has to deviate from the plan if something unexpected happens. Flexibility in carrying out a plan is a characteristic of a good teacher. The last, but most important, principle guiding a lesson plan is assessment. The plan should include assessment criteria for each activity, and the teacher should be familiar with these standards, which may have different formats such as checklists, grading scales, questions to be answered or even aspects to be observed. These criteria are crucial because they determine the degree of success of each classroom activity, and they help the teacher make informed decisions about future lesson plans.

Furthermore, planning effective lessons should be a satisfying and enjoyable experience. It should be a source of learning for the teacher and provide some fun and challenge for the learners. The template presented in this article intends to guide novice teachers and trainees in their planning so that they do not feel overwhelmed and can enjoy planning. If teachers experience pleasure and joy when planning, they will definitely transmit these feelings to the learners, who will certainly benefit from this teacher attitude.

Finally, we cannot forget that even carefully prepared plans do not work out as planned. In spite of the importance of planning, a lesson plan is not carved in stone; it can be changed according to new circumstances. A lesson plan is not meant to keep a teacher from changing the duration of an activity or giving up an activity if the situation demands some different actions. A good lesson plan guides; it does not dictate what and how we teach. A good lesson plan is not the only key to success, but it increases student achievement, reduces teacher anxiety and helps students undergo an effective process of learning, the ultimate goal of teaching a foreign language. 


\section{References}

Bailey, Kathleen M. and David Nunan. (eds.) 1996. Voices from the Language Classroom. Cambridge: Cambridge University Press.

Brown, James Dean. 1995. The Elements of Language Curriculum: A Systematic Approach to Program Development. Boston: Heinle \& Heinle Publishers.

Celce-Murcia, Marianne (ed.) 2001. Teaching English as a Second or Foreign Language. Boston: Heinle \& Heinle.

Davies, Paul and Erick Pearse. 2000. Success in English Teaching. Oxford: Oxford University Press.

Díaz Maggioli, Gabriel H. 1995. Managing Learning Styles in the Classroom. Alexandria, VA: Teachers of English to Speakers of Other Languages, Inc.

Doff, Adrian. 2000. Teach English: A training course for teachers. Cambridge: Cambridge University Press.

Graves, Kathleen. 2000. Designing Language Courses: A Guide for Teachers. Boston: Heinle and Heinle Publishers.

Nation, Paul. 2001. Learning Vocabulary in Another Language. Cambridge: Cambridge University Press.

Propst, David. 1997. "Same Old Dog, New Tricks: Lesson Planning as Friend not Foe”. English Teaching Forum, October.

Richards, Jack C. 1998. Beyond Training. Cambridge: Cambridge University Press.

Richards, Jack and Charles Lockhart. 1995. Reflective Teaching in Second Language Classrooms. New York: Cambridge Language Education.

Richards, Jack and Theodore Rodgers. 2001. Approaches and Methods in Language Teaching. Cambridge: Cambridge University Press.

Ur, Penny. 1996. A Course in Language Teaching: Practice and Theory. Cambridge: Cambridge University Press. 
Williams, Marion and Robert L. Burden. 1997. Psychology for Language Teachers: A social constructivist approach. Cambridge: Cambridge University Press.

Woodward, Tessa. 2001. Planning Lessons and Courses: Designing Sequences of Work for the Language Classroom. Cambridge: Cambridge University Press.

\section{Appendix 1}

Please answer the following question:

This year we required Practicum students to use a standard template for their lesson plans. How useful was this template to plan your lessons? Why? Rate its usefulness using the following scale:

5

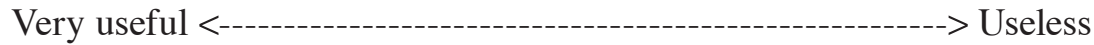

